\title{
Communication Strategy through Language Choice
}

\author{
Ely Triasih Rahayu ${ }^{1}$. Muhammad Sulthan2 \\ ${ }^{1}$ Japanese Language Study Program Jenderal Soedirman University \\ e-mail: hikarinihongo@gmail.com \\ ${ }^{2}$ Communication Departement of Jenderal Soedirman University \\ e-mail: sulthan.muhammad@yahoo.com
}

\begin{abstract}
This research is aimed at investigating communication strategy through language choice. Language choice here means the choice of language variation in Javanese and Japanese speech level. The problem focuses on how negotiations of language choice are applied in formal communication. This is a furthered research which allows the data taken from the result of research on the comparison of Javanese (basa krama) and Japanese (keigo) honorific language presented in an international seminar in Korea. The data of this research comprise krama utterances and keigo utterances which were then analyzed through contextual analysis method. According to the form of data analysis, this is a qualitative research. Furthermore, the result is presented in a narrative deep analysis. The aim of the research is to describe appropriate language choice in krama and keigo variation as the manifestation of suitable communication strategy. The communication strategy through negotiating the language choice enables interlocutors to reach a mutual communication.
\end{abstract}

Keywords: Communication Strategy, Language Choice,Language Variation

\section{Introduction}

In conducting social interaction at any place, communication strategy is undoubtedly required. For multilingual speech community, language choice becomes a complex issue since language as a means of communication is not only comprehended based on its utterance form but also social norms in the society in which social interaction system as well as social level exist.

One of the communication strategies can be shown through negotiation by choosing appropriate language. The language choice cannot be randomly performed; rather, several considerations such as who is speaking to whom, what topic is about, and where it takes place have to be taken. Consequently, each member of speech community has to selectively make use of certain language style which is appropriate in certain situation. Communication strategies through language choice enable interlocutors to reach a mutual and smooth conversation. The communicator competence in choosing suitable language would enhance the communication quality. Otherwise, the breakdown of choosing language may result in miscommunication between participants. If one fails to choose the right language form, moreover, it is considered to be impolite or incompetent in using language.

This research analyzed language choice especially related to honorific language in formal situation or language choice in formal communication. The languages used in this research are Javanese and Japanese language. The main consideration in choosing those language is that both Javanese and Japanese speech community put a deep concern on the language use according to speech level by considering social status. For instance, an employee of a company would make use of honorific language to his manager to give respect; likewise, a student to his teacher would do so. A new employee would make use of honorific language to other employees 
yet when the closeness is established, the formal language would be shifted.

This is a 2012, Indonesian Directorate of Higher Education, Fundamental Grant Research Program. In this second year, the data were directly taken from Japanese and Javanese native speakers. There are 4 Javanese native speakers and 5 Japanese native speakers as respondents. The Javanese respondents were teachers of a school in which obliges its teachers to use Javanese on Thursdays while Japanese respondents were employees of accessories company, automotives company and supermarket. Both domains were chosen by considering that the honorific language is still preserved. Honorific and formal language is still used when utterances are produced by student to teacher, teacher to headmaster, employee to manager or superior. The data were studied through two perspectives; first, to know the similarities and differences of honorific language in Japanese and Javanese speech community. The research has been presented in Korea in May 14-18, 2014. Second, the same data were analyzed in this furthered research focusing on honorific language choice in Japanese and Javanese speech community as communication strategy in formal situation namely school and workplace domain. It employed contextual method since the language choice is viewed from utterance form and the background of utterance (linguistic and nonlinguistic factors).

\section{Literature Review}

Multilingual community actually has performed language choice in their interaction. The language choice in certain community is studied through sociolinguistic perspective which concerns with language and its relation to the society (Holmes,
1992: 1). Scientific studies to reveal this phenomenon have been conducted by sociolinguists in some countries (Gumperz, 1972 and Fasold, 1984). The phenomenon of language choice is common for dynamic community. This community continues changing which influences its social structure including language use.

This research applied the concept of language choice proposed by Gumperz (1988):

Negotiation in conversation is a playing out of a negotiation for position in community at large. It is made up of implicit and explicit strategies for seeking the kind of information that seems necessary in order for participants to be able to hold a conversation.Strategy in choosing language can be either implicit or explicit. An implicit strategy deals with language form based on the correct grammatical system (lexically, morphologically and semantically). Meanwhile, explicit strategy focuses on the language use according to social and cultural norm such as norms of interaction and interpretation in which the language is used. The competence of comprehending those norms is, according to Hymes, called as communicative competence.

Dell Hymes (1973) is the one who introduced the term communicative competence. He said that language choice does not only focus on its grammar. Grammatically, utterance produced by an employee to his colleague, " Baju anda tidak rapi, apakah istri tidak menyetrika baju?". This utterance is correct grammatically yet it is inappropriate. In sociolinguistics, it deals with the language use by considering social factor. This is called nonlinguistic factor. The utterance shows inappropriateness of language use in workplace domain. This rule mainly discusses about nonlinguistic factor which influence the speech style or known as components of speech. 
This concept was introduced by Hymes (1973) by its acronym SPEAKING (Scene/Setting, Participants, Ends, Act sequence, Key, Instrumentalities, Norms, and Genre).

Setting of utterance means place in which the conversation takes place. The choice of language in an utterance would accommodate where the conversation occurs such as office, school, beach, family and market while the speech scene refers to in what situation or atmosphere the conversation takes place. It can be either formal or informal. The language choice in formal utterance is truly needed when one talks to his superior in office. In contrast, it would sound awkward if it is used in reunion of old friends.

Participants refer to the speaker, hearer, and one about whom the participants talk. The language choice of interlocutors depend the difference of vertical and horizontal dimension. The first dimension includes age, social status, and social role in the society. The speaker is expected to choose the appropriate language when he speaks to superior. The second dimension involves the degree of closeness between among participants.

Ends refer to purpose of utterance uttered by the speaker. It also relates to expectation after message content was delivered by the speaker. Act sequence can be delivered either individually or socially. Sometimes, the change of topic consecutively occurs in a speech act. It surely affects the language choice. Key refers to verbal and nonverbal act. The key can be the change of tone which provides clue whether the speaker is glad, sad, disappointed, serious, etc. Nonverbal key can be in the form of gesture, facial expression and eye contact. Nod and wink may identify that one agrees although he says nothing.
Instrumentalities refer to the means of speech whether written, spoken or sign. Spoken can be conducted via telephone while written can be represented by facsimile and sign is done by semaphore.

Norms deals with the rule in communication. It is the norms that govern whether it is allowed or not to do something by the participants in speech act. One can be considered impolite if he violates the norms. In Japanese speech community, one can be considered impolite to ask personal issue such as age, children, marital status, etc.

Genre is kind of speech that can be differentiated from its form, whether it is poem, prose or drama script.

\section{Discussion}

In Javanese speech community, language politeness takes high position. The politeness is applied based on social factors in the community which relies on Javanese norms. The utterance of children to parent (family domain) would be considered impolite if they use ngoko (low level) form. The following is utterance of krama (high level/ respectful) by child to the parent:

(1) Son : Pak, artonipun dipun betho kondur. (DT.K.12)

'Dad, the money was brought home.'

Father: Digawa ibumu yo le.

'Your mother brought it.'

Son : Nggeh wau.

'Yes, she did.'

The utterance above shows that Javanese speech community, children show their respect to their parents by making use of krama form while parent uses ngoko. 
(2) Teacher:Njih Pak, mbenjang dalem sowan. (DT.K.5)

'Yes, Sir. I would come by tomorrow.' Headmaster: Jam wolu yo soale nek awanana pertemuan karo kepalasekolah SMK siji.

'At eight, will you? since I have a meeting with theheadmaster of SMK one in the afternoon.'

In the utterance above, the teacher uses krama to respect the headmaster while the headmaster uses ngoko in order to show closeness between super ordinate and subordinate. However, if the subordinate (teacher) is older than the super ordinate (headmaster), the headmaster will use krama in his utterance.

In the meantime, children in Japanese speech community to their parents tend to use futsuukei (low level). From the interview to the respondents, the use of honorific language in Japanese community has faded away. Japanese youngsters do not really employ honorific language to their parents. Even in family domain, children tend to use futsuukei as follows:

(3) Son : Okaasan, ashita doko e iku?

'Mom, where are we going to tomorrow?'

Mother:Otoosan ni kiite..

'Ask your dad.'

According to Ogami Takashi (a housewife of two children lived in Chiba), her two daughters do not use keigo since closeness has been established between children and parents. Closeness relationship enables to create an open communication among them. Children do not reluctant to tell their personal problems to their parents. Then according to Takeru Yaguchi (an employee of Statistic Company lives in Eastern Osaka) said that keigo can be effectively applied in the company. Takeru was even trained to use keigo when he came to the company. Company is the place where people seek service so the use of language is very considered. Sometimes, the use of honorific language correctly can bring the successful marketing to the company. The following is the utterance in office domain:

(4) Takeru : Anou shachou, tetsudaimasuka.

'Excuse, Sir, What can I do for you?'

Director: Ee, Takeru kun. tanomuyo.

'Ee, Takeru. I need your help.'

Kono andaarain no bubun ga wakaranaindakedo.

'I don't know which one should be underlined.'

Takeru : Hai. Kore wa watashi ga okakishimasu.

'Ok, let me do it.'

The utterance above is produced by an employee who uses sonkeigo form toward his director. Utterances in office domain in Japan differentiate sub ordinate utterance from super ordinate utterance. If super ordinate is younger than sub ordinate then the sub ordinate still uses sonkeigo to the super ordinate, otherwise, if the sub ordinate is older than the super ordinate then the super ordinate does not have to use sonkeigo. In Japanese speech community, position or title truly influences the language form regardless the age difference. It shows that Javanese and Japanese use of honorific language is different. In Javanese, the use of honorific language based on position/title and age while Japanese community more considers 
office domain (position/rule) and regardless the age difference.

Uchi soto 'in-out group' is the distinct feature of Japanese speech level. Uchi means member of speaker's group while soto adalah is member of hearer's group. Speaker's group can be member of family/ company (own environment) while other group means hearer's family or company. It is unique and distinctive since its rule is in contrast with the language choice. A sub ordinate should use sonkeigo to respect the super ordinate but the sub ordinate in uchi soto system would utters the reverse in which they use kenjougo (low level) to lower the act of super ordinate. It aims to respect hearer of other company.

System of uchi soto is also different from Japanese speech level system in terms of speaker would always krama inggil (honorific language) to either super ordinate or hearer of other company. Javanese language does not recognize in-out group.

\section{Concluding Remark}

Both Javanese and Japanese speech community recognize speech level which makes use of honorific language (krama and keigo) in the utterance. In its application, the speaker has to be able to select appropriate language in the effort of respecting the hearer. The system of both language speech levels employs honorific language to show respect. Javanese speech community makes use of honorific language in family domain while Japanese speech community does not. Rather, the honorific language is mainly used in office domain for business communication. Then, Japanese speech community recognize uchi soto which differentiates speech event involving speaker's own group and hearer's group.

\section{Acknowledgement}

This research was financially supported by Indonesian Directorate of Higher Education Grant Research Program.

\section{Bibliography}

(1) Fasold, Ralph. (1984). The Sociolinguistics of Society. Oxford: Basil Blackwell

(2) Gumperz, John J.(1982). Language and Social Identity. London: Cambridege University Press

(3) Holmes, Janet.(1992). An Introduction to Sociolinguistics. New York: Addision Wesley Logman Inc

(4) Hymes, Dell, ed.(1973). Foundations in Sociolinguistics An Ethnographics Approach. Philadelpia: University of Pennsylvania Press

(5) Rahayu, Ely Triasih. (2013).Sistem dan Bentuk Tingkat Tutur Bahasa Jepang dalam DomainPerkantoran.Disertation.Surakarta:UNS

Rahayu,ElyTriasih and Sultan, Muhammad. (2014). Comparison of Honorific Language in Javanese Speech Community. (Proceding) Seoul:HU 